\title{
Water quality quantification: basics and implementation
}

\author{
A. Parparov ${ }^{1, *}$, K.D. Hambright ${ }^{1,2}$, L. Hakanson ${ }^{3}$ \& A. Ostapenia ${ }^{4}$ \\ ${ }^{1}$ Israel Oceanographic and Limnological Research, Kinneret Limnological Laboratory, Migdal, Israel \\ ${ }^{2}$ Department of Zoology, University of Oklahoma Biological Station, Kingston, OK, USA \\ ${ }^{3}$ Department of Earth Sciences, Uppsala University, Uppsala, Sweden \\ ${ }^{4}$ Laboratory of Hydroecology, Belarus State University, Minsk, Belarus \\ (*Author for correspondence: E-mail: parpar@ocean.org.il)
}

Received 18 October 2005; in revised form 27 October 2005; accepted 28 October 2005

Key words: water quality assessment, Lake Kinneret, Naroch Lakes, limnology, sustainable management

\begin{abstract}
Quantitative estimation of water quality and its relationships with management activities is a necessary step in efficient water resources management. However, water quality is typically defined in abstract terms and management activities are rarely quantified with respect to their impact on lake water quality. Here we show by demonstration of systems for Lake Kinneret, Israel and the Naroch Lakes of Belarus how water quality can be quantified in relation to lake management activities to be a part of sustainable management.
\end{abstract}

\section{Introduction}

"Water quality" is the term widely used in multiple scientific publications and normative documents relating to the necessities of "sustainable" and "optimal" management of water resources.The terms "water quality", "sustainable" and "management" require concrete and quantitative definitions of basic concepts: such as the objects and objectives of management, the environmental steady state (e.g., a "reference value") which should be sustained, and ecological and socioeconomic effects of the management. Quantification of water quality is a challenging scientific problem and its solution should be an important stage in development of scientific background of water resources management (Ryding \& Rast, 1989; Chapman, 1992; Hakanson \& Peters, 1995; Parparov \& Hambright, 1996; Boon \& Howell, 1997; Hakanson et al., 2000; WFD, 2000).

In this presentation we consider aspects of water resources management associated with the quantification of water quality (WQ). The problem itself: quantification of quality sounds rather oxymoronic. However, the task of optimal water resource management requires predefined standards of water quality as integral components of the optimization criteria (Kalceva et al., 1982; Straskraba \& Gnauck, 1985). Thus water quality should be expressed in measurable form to allow analytical expression of relationships between water quality and various driving factors that can affect water quality (e.g., external nutrient loading, intensity of water supply).

The methodological approaches allowing quantitative expression of water qualilty are well known (Horton, 1965; Brown et al., 1970; Ott, 1978; Smith, 1987; 1990). Practical implementations of these concepts have been concentrated in the US, while examples of quantitative estimates of lake water quality in Europe have been relatively rare. In many cases, particularly in the US, trophic classification was used as a gross indicator of water quality (U. S. Environmental Protection Agency, 1974). For example, oligotrophic lakes are considered to be of "good" water quality; and eutrophic lakes of "bad" water quality (e.g., see Fozzard et al., 1999). Such a system of trophic classification 
allows one to rank lakes according to their productivity, oxygen and nutrient regime and thereby evaluate water quality changes (i.e., trophic state changes) in response to various driving forces.

Water quality management then requires asking (1) Is current water quality "good" or "bad"? and (2) Will the management scenario under consideration (e.g., change in commercial fishing pressure, reduction in surface inflow) result in an increase or decrease in water quality? It is obvious that oligotrophication of a fishpond or eutrophication of a drinking water reservoir should be equally considered as water quality deterioration. We suggest that detailed and concrete definitions of water quality indices that take into consideration specific characteristics and uses of a given water resource (e.g., lake) can provide managers with a necessary tool for formulating optimal management strategies, particularly for water resources that serve multiple uses.

Here we describe our development of the quantification of water quality and its implementation in Lake Kinneret, Israel and the three Naroch Lakes (Batorino, Miastro and Naroch) of Belarus.

\section{Material and methods}

\section{Study sites}

\section{Naroch Lakes}

The Naroch Lakes consist of three connected basins, Lakes Batorino, Miastro and Naroch. These kettle lakes are located in Northwest Belarus (Fig. 1). The limnology of the Naroch Lakes has been intensely studied (Winberg, 1985). Most pollution flowing into the Naroch Lakes is

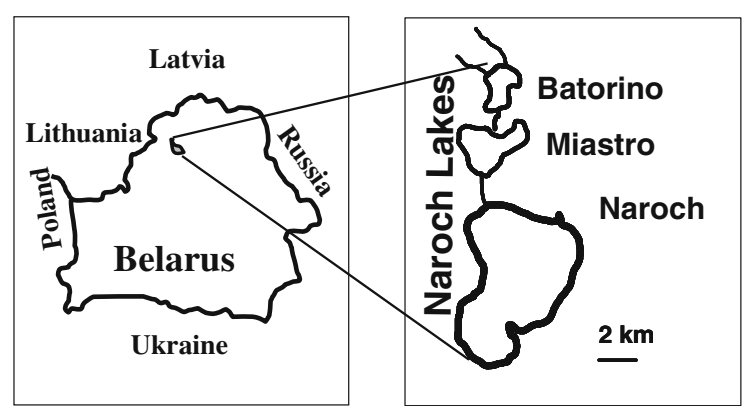

Fig. 1. The Naroch Lakes and their location in Belarus. entrapped upstream (mostly in Batorino, but also Miastro). Thus, WQ and hence, aesthetical and recreational potential, in downstream Lake Naroch is relatively high compared with Lakes Batorino and Miastro.

Until the mid 1980s, Lake Batorino was considered as highly eutrophic; Lake Miastro as eutrophic, and Lake Naroch as mesotrophic. The trophic state of all three Naroch lakes declined (i.e., oligotrophied) substantially during the last decade (Table 1). The main factors responsible for this oligotrophication are 1) a decrease of external nutrient load following a decline in general economic activity, 2) instigation of remedial measures in the catchment area, and 3) the introduction of molluscan filtrator Dreissena polymorpha (Ostapenya, 1999).

The oligotrophication of the Naroch Lakes constituted water quality deterioration with respect to the primary uses of Naroch waters (Ostapenya, 1999; Hakanson et al., 2000): conservation (due to invasion of Dreissena polymorpha); recreation (due to increase of areas occupied by macrophytes), and commercial fisheries (due to lowering of the overall lake productivity).

\section{Lake Kinneret (Israel)}

Lake Kinneret (the Biblical Sea of Galilee, the largest fresh water body of the Middle East) is a subtropical eutrophic lake located at about $-210 \mathrm{~m}$ altitude (i.e., below mean sea level) in the northern part of the Dead Sea Rift Valley (Fig. 2). The limnology of the lake is well-documented (Serruya, 1978). The main inflow (60 to $80 \%$ of the total) is via the Jordan River, while the main outflow is Israel's National Water Carrier, supplying ca. one-third of the country's freshwater needs. The water level of the lake depends on climatic inputs and withdrawal for water supply (Serruya, 1978, Hambright et al., 1997).

The lake is $\sim 22 \mathrm{~km}$ long and $12 \mathrm{~km}$ at maximum width; maximum and mean depths are 42 and $24 \mathrm{~m}$, respectively, and the surface area is $170 \mathrm{~km}^{2}$. The lake is amictic during most of summer and fall, with surface temperatures approaching $30{ }^{\circ} \mathrm{C}$ (Hambright et al., 1997). The hypolimnion becomes anoxic shortly after formation.

Lake Kinneret is meso-eutrophic with a mean annual primary production of $650 \mathrm{~g} \mathrm{C} \mathrm{m}^{-2}$ 
Table 1. Limnological indices of the Naroch Lakes in 1977-1988 (I) and in 1989-1999 (II) (avg for ice-free season)

\begin{tabular}{|c|c|c|c|c|c|c|}
\hline \multirow[t]{2}{*}{ Indices } & \multicolumn{2}{|c|}{ Naroch } & \multicolumn{2}{|c|}{ Miastro } & \multicolumn{2}{|c|}{ Batorino } \\
\hline & I & II & I & II & I & II \\
\hline $\mathrm{S}, \mathrm{m}$ & 5.1 & 6.1 & 1.7 & 3.8 & 0.78 & 1.1 \\
\hline TSS, $\mathrm{mg} \mathrm{L}^{-1}$ & 1.81 & 0.96 & 6.2 & 2.29 & 16.7 & 9.2 \\
\hline $\mathrm{BOD}_{5}, \mathrm{mgO}_{2} \mathrm{~L}^{-1}$ & 1.06 & 1.03 & 2.05 & 1.39 & 3.55 & 2.63 \\
\hline $\mathrm{C}_{\mathrm{tot}}, \mathrm{mg} \mathrm{L}^{-1}$ & 5.36 & 5.23 & 8.76 & 7.99 & 14.6 & 13 \\
\hline $\mathrm{N}_{\mathrm{tot}}, \mathrm{mg} \mathrm{L}^{-1}$ & 0.87 & 0.58 & 1.14 & 0.70 & 1.62 & 0.94 \\
\hline $\mathrm{P}_{\mathrm{tot}}, \mu \mathrm{g} \mathrm{L}^{-1}$ & 28 & 16 & 52 & 34 & 84 & 44 \\
\hline $\mathrm{Chl}, \mu \mathrm{g} \mathrm{L}^{-1}$ & 4.9 & 2.0 & 20.0 & 4.9 & 50.1 & 11.4 \\
\hline
\end{tabular}

$\mathrm{S}$ - Secchi depth, TSS - Total Suspended Solids; $\mathrm{C}_{\mathrm{tot}}-$ Total Carbon; $\mathrm{N}_{\text {tot }}-$ Total Nitrogen; $\mathrm{P}_{\mathrm{tot}}-$ Total Phosphorus; Chl - chlorophyll concentration (Ostapenya, 1999).

(Berman et al., 1995) and Secchi depths varying from 0.7 to $5.5 \mathrm{~m}$. A prominent biological feature of the lake has been the spring bloom of the dinoflagellate Peridinium gatunense (Pollingher, 1978; Berman et al., 1992), though since 1994, the lake has exhibited uncharacteristic developments in the phytoplankton assemblage, including the first-ever bloom of a potentially toxic, $\mathrm{N}_{2}$-fixing cyanobacteria (Pollingher et al., 1998). Further detail on the basic ecology of Lake Kinneret can be found in Serruya, (1978).

Since 1965 (the inception of National Water Carrier of Israel), and with the economic and population growth both within the region and in Israel, the main uses of Lake Kinneret waters have been consumptive - domestic "drinking water" supply and agricultural irrigation (Shamir et al.,
1985). Owing to its historical significance and climatic characteristics, the lake has large recreational potential. The lake is also supports a relatively large commercial fishery (Ben-Tuvia et al., 1992).

\section{Methodology of Water Quality Quantification}

\section{Basic principles}

We have suggested the following principles of the WQ assessment as the initial stage of the quantification process (Parparov \& Hambright, 1996; Hambright et al., 2000):

1. The system of water quality indices (WQI) and their acceptable ranges must be decided upon and quantified by an expert panel consisting of all partners in lake management:

\section{SRAEL}

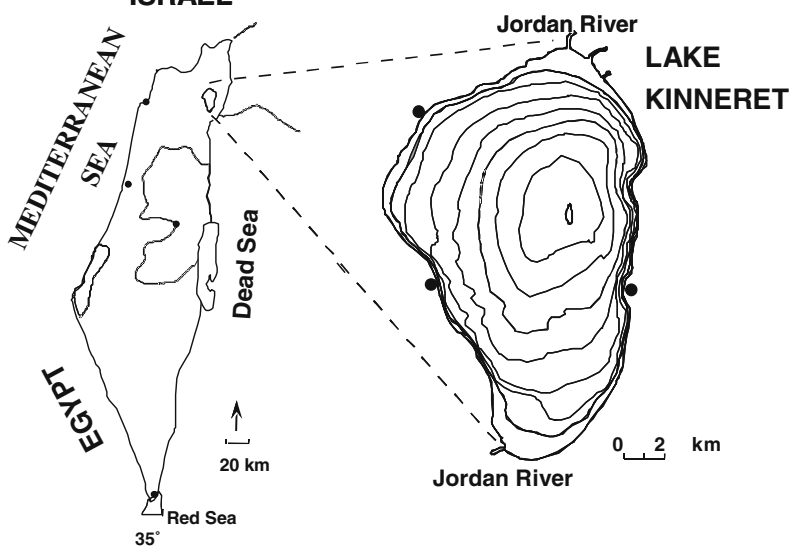

Figure 2. Lake Kinneret and its location in Israel. 


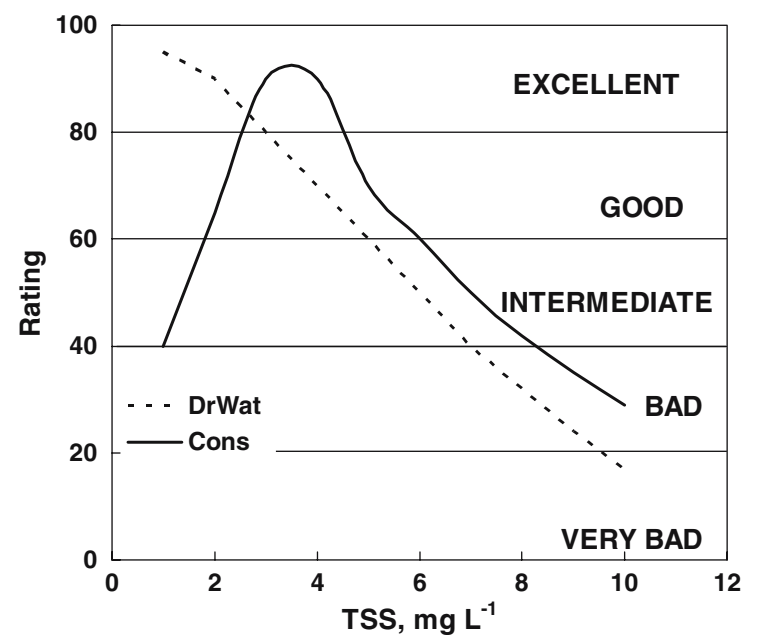

Figure 3. Typical forms of the rating curves connecting quantitative value of water quality (Rating) with the value of the water quality index (here total suspended solids, TSS) for different water uses: the ecosystem conservation (Cons) and the drinking water supply (DrWat) established by the expert panel for Lake Kinneret. The acceptable WQ corresponds to $60<\mathrm{R}<100$ (from 'GOOD' to 'EXCELLENT').

Water Suppliers and Users, Limnologists, Fishermen and Fish-Farmers.

2. The WQIs and their driving processes must be suitable for mathematical modeling.

3. The WQIs and the model together should serve as a self-organizing tool for lake management.

4. The WQI must be dynamic and adaptable to changes in ecosystem functioning.

Assessment of $W Q$ Indices and their permissible ranges

Our approach to water quality assessment (i.e., establishment of the system of water quality indices and their permissible ranges) was based on quantitative modifications of the expert panel method (Ott, 1978; Brown et al., 1970; Smith, 1987; 1990). This step (as regards to Lake Kinneret) was described in detail in Hambright et al. (2000). Here we provide a brief overview of the approach. Initially, the correspondence between the ecological values of WQI (e.g., nutrient concentration or Secchi depth)) and some numeric Rating value $(0<\mathrm{R}<100)$ was established in a form of a rating curve (Fig. 3).

$$
\mathrm{R}=\mathrm{f}(\mathrm{WQI})
$$

Long-term monitoring data, including frequency distributions, means and standard deviations of physical, chemical and biological parameters in Lake Kinneret (1969-1992) and the Naroch Lakes (1970-2000) were provided to separate expert panels for each lake. The panels were asked to choose about 10 parameters most indicative of water quality in the studied lakes, and to construct rating curves for each parameter, spanning the entire range of values observed in the lake. "Acceptable ranges" for the separate water quality indices were restricted to the range 60-100. Rating curves from individual panel members were averaged for each index. Linear approximations of ratings and parameter values were used to construct graphic presentations of the temporal dynamics of the WQIs (Hambright et al., 2000).

\section{Results}

The establishment of a system of water quality indices

For Lake Kinneret and the Naroch Lakes, the rating curves were established under the assumption that conservation of the lake ecosystem is the prime objective for the resource managers. The 
rating curves will vary based on the prime objective for management of the lake and the form and the shape of the rating curves will be strongly affected by the priorities of water use (e.g., ecosystem conservation or drinking water supply, see Fig. 3). Integration of the rating curves into the single "national" water quality curve should be done according to priorities established for the main directions of the water resources use. Such priorities were established for the Naroch Lakes (Table 2). The priorities of the water resources uses for Lake Kinneret are under consideration.

The established dependence (eq. 1) allows assessment of the permissible ranges of WQI:

$$
\begin{aligned}
& \left\{\mathrm{WQI}_{\mathrm{LOW}}<\mathrm{WQI}_{\mathrm{C}}<\mathrm{WQI}_{\mathrm{HIGH}}\right\} \\
& \Leftrightarrow 60<\mathrm{R}(\mathrm{WQI})<100,
\end{aligned}
$$

where $\mathrm{WQI}_{\mathrm{C}}$ is the current value of the index; $\mathrm{WQI}_{\text {LOW }}$ is the lower permissible value and $\mathrm{WQI}_{\mathrm{HIGH}}$ is the upper permissible value of the index; $\Leftrightarrow$ means correspondence.

The established systems of water quality indices for conservation LK and the Naroch Lakes are presented in Tables 3 and 4.

For Lake Kinneret, we distinguished between two ecologically different periods owing to the magnitude of influence from the watershed and the well-documented bloom period of the dinoflagellate Peridinium (see Serruya, 1978). Therefore, separate WQ ratings and parameter value relationships were established for these two periods. The established system (Table 3 ) characterizes water quality of the upper layer $(0-15 \mathrm{~m})$ of Lake Kinneret water. This water layer approximately corresponds to the euphotic zone and

Table 2. Priorities of the separate directions of the Naroch Lakes water resources use (in relative units) as established by the expert panel (Ostapenya, 1999; Hakanson et al., 2000)

\begin{tabular}{llll}
\hline \multirow{2}{*}{ Directions } & \multicolumn{2}{l}{ Lakes } & \\
\cline { 2 - 4 } & Naroch & Miastro & Batorino \\
\hline Conservation & 54 & 49 & 49 \\
Recreation & 32 & 25 & 13 \\
Fishery & 13 & 23 & 34 \\
Water supply & & 3 & 3 \\
Other & 1 & & 1 \\
\hline
\end{tabular}

epilimnion (during thermal stratification) in Lake Kinneret.

\section{Quantification of the relationships between $W Q$ and management}

Establishment of the correspondence (if possible, functional) between the intensity of the management measures (MM) and the water quality changes caused by these measures, i.e.

$$
\mathrm{WQI}=\Phi(\mathrm{MM})
$$

should be the next stage in quantification of water quality.

Here, we apply the simplest regressional analyses to simulate potential relationships between management measures (phosphorus loading for Naroch Lakes and the intensity of water supply for Lake Kinneret) and water quality indices (Fig. 4) for each lake. Being compared with the observed limnological trends (e.g., increase of salinity with the lake water level lowering in Lake Kinneret, or increase of water transparency with lowering of the phosphorus loading in Lake Naroch), these dependences are useful for illustrating the process of the WQ quantification.

\section{Discussion}

\section{The levels of WQI integration}

Depending on both the target audience and the level of communication required, we propose three separate levels of WQI integration:

(A) An expanded system of water quality indices (Tables 3 and 4): This is the base system that is suitable for describing different aspects of water resources use; it serves as a "common language" for communication between partners in management.

(B) Reduced system of WQI: Modeling WQ using an expanded system (e.g., of 11 parameters for Lake Kinneret) will lead to relatively high uncertainties of the estimates. Therefore, the number of WQ parameters and their WQIs should be reduced using such techniques as correlation analysis or other traditional mathematical methods of minimization. This minimized system 
Table 3. Acceptable winter-spring and summer-autumn ranges $(100 \geq$ Rating $\geq 60)$ for selected water quality parameters for conservation of Lake Kinneret ecosystem. The WQIs included into the 'Reduced' WQI system are shown in bold (Parparov and Hambright, 1996; Hambright et al., 2000)

\begin{tabular}{|c|c|c|}
\hline Indices & Winter-Spring & Summer-Autumn \\
\hline Chloride, $\mathrm{mg} \mathrm{L}^{-1}$ (Cl) & $184-244$ & $184-246$ \\
\hline Total suspended solids, mg L $^{-1}$ (TSS) & $1.0-7.1$ & $0.6-4.1$ \\
\hline Turbidity, NTU (Tu) & $1.2-4.9$ & $0.7-3.0$ \\
\hline Total phosphorus, $\mu \mathrm{g} \mathrm{L}^{-1}$ (Ptot) & $9-38$ & $5-28$ \\
\hline Total nitrogen, $\mathrm{mg} \mathrm{L}^{-1}$ (Ntot) & $0.3-1.2$ & $0.2-0.9$ \\
\hline Chlorophyll, $\mu \mathrm{g} \mathrm{L}^{-1}$ (Chl) & $5.5-40.5$ & $1.5-10.1$ \\
\hline Primary production, g $\mathrm{C} \mathrm{m}^{-2} \mathrm{~d}^{-1}(\mathrm{PP})$ & $1.1-3.2$ & $0.7-2.2$ \\
\hline Cyanobacteria, $\%$ total biomass $(\%$ Cyano $)$ & $0-3.7$ & $1-10.8$ \\
\hline Biomass of Zooplankton, $\mathrm{g} \mathrm{m}^{-2}$ (Bzp) & $13-52$ & $7-37$ \\
\hline Fecal coliforms, No. $100 \mathrm{~mL}^{-1}$ (Fcoli) & $0-1000$ & $0-500$ \\
\hline $\mathrm{BOD}_{5}, \mathrm{mg} \mathrm{O}_{2} \mathrm{~L}^{-1}$ & $0.96-3.96$ & $0.54-1.38$ \\
\hline
\end{tabular}

should represent a set of target variables for mathematical modeling (see Table 3 ).

(C) Composite Water Quality Index, CWQI: Trials to express water quality as an integrated or composite value have a long tradition in limnology (e.g., a trophic state index (Carlson, 1977) or Lake Ecosystem Index (Hakanson \& Peters, 1995)). This highest level of integration of water quality estimating should be suitable for communication with the policy makers and optimization of management.
Usually, the CWQI is calculated using different methods of averaging. To illustrate how the estimates of the "overall" water quality depend on the algorithm of the CWQI evaluating we calculated CWQI dynamics in Lakes Kinneret and Naroch as the arithmetic mean of the separate rating values, the weighted average and the minimum operator of D. Smith (the CWQI value in the last case corresponds to the lowest rating value in the entire set of the water quality indices, Smith (1987; 1990),

Table 4. The set of the water quality indices and their acceptable ranges (for the "Conservation" use) for the Naroch Lakes (Ostapenya, 1999; Hakanson et al., 2000)

\begin{tabular}{|c|c|c|c|}
\hline Indices & Naroch & Miastro & Batorino \\
\hline Secchi depth, m & $4.7-7.9$ & $2.1-5.4$ & $0.7-2.1$ \\
\hline Total Suspended Solids, $\mathrm{mg} \mathrm{L}^{-1}$ & $0.3-2.5$ & $0.6-2.6$ & $4.3-18.0$ \\
\hline Chlorophyll, $\mu \mathrm{g} \mathrm{L}^{-1}$ & $0.8-6.9$ & $3.1-28.4$ & $7.0-72.0$ \\
\hline Oxygen, $\%$ Saturation, at surface & $>70-120$ & $>70-150$ & $86-139$ \\
\hline Oxygen, \% Saturation, near bottom & $58-110$ & $62-120$ & $65-147$ \\
\hline Total Nitrogen, $\mathrm{mg} \mathrm{L}^{-1}$ & $0.29-1.23$ & $0.39-1.90$ & $0.54-2.02$ \\
\hline Total Phosphorus, $\mathrm{mg} \mathrm{L}^{-1}$ & $0.01-0.04$ & $0.02-0.07$ & $0.03-0.10$ \\
\hline Total Carbon, $\mathrm{mg} \mathrm{L}^{-1}$ & $3.9-6.3$ & $6.4-9.4$ & $9.0-16.4$ \\
\hline Primary Production, $\mathrm{mg} \mathrm{C} \mathrm{m}^{-3} \mathrm{~d}^{-1}$ & $24-64$ & $66-276$ & $141-525$ \\
\hline Destruction, $\mathrm{mg} \mathrm{C} \mathrm{m}^{-3} \mathrm{~d}^{-1}$ & $125-78$ & $45-220$ & $70-426$ \\
\hline Phytoplankton Biomass, $\mathrm{g} \mathrm{m}^{-3}$ & $0.3-1.9$ & $1.0-7.2$ & $3.0-23$ \\
\hline Cyanobacteria, $\%$ of algal biomass & $0.10-24$ & $4-29$ & $10-48$ \\
\hline $\mathrm{BOD}_{5}, \mathrm{mg} \mathrm{O}_{2} \mathrm{~L}^{-1}$ & $0.6-1.7$ & $1.0-2.3$ & $1.7-4.1$ \\
\hline Zooplankton Biomass, $\mathrm{g} \mathrm{m}^{-3}$ & $0.7-2.26$ & $1.0-6.2$ & $2.2-16.1$ \\
\hline $\mathrm{pH}^{*}$ & \multicolumn{3}{|l|}{$8.15-8.55$} \\
\hline Surface area accupied by macrophytes & \multicolumn{3}{|c|}{ Should be established } \\
\hline
\end{tabular}

*- for Lake Naroch only. 

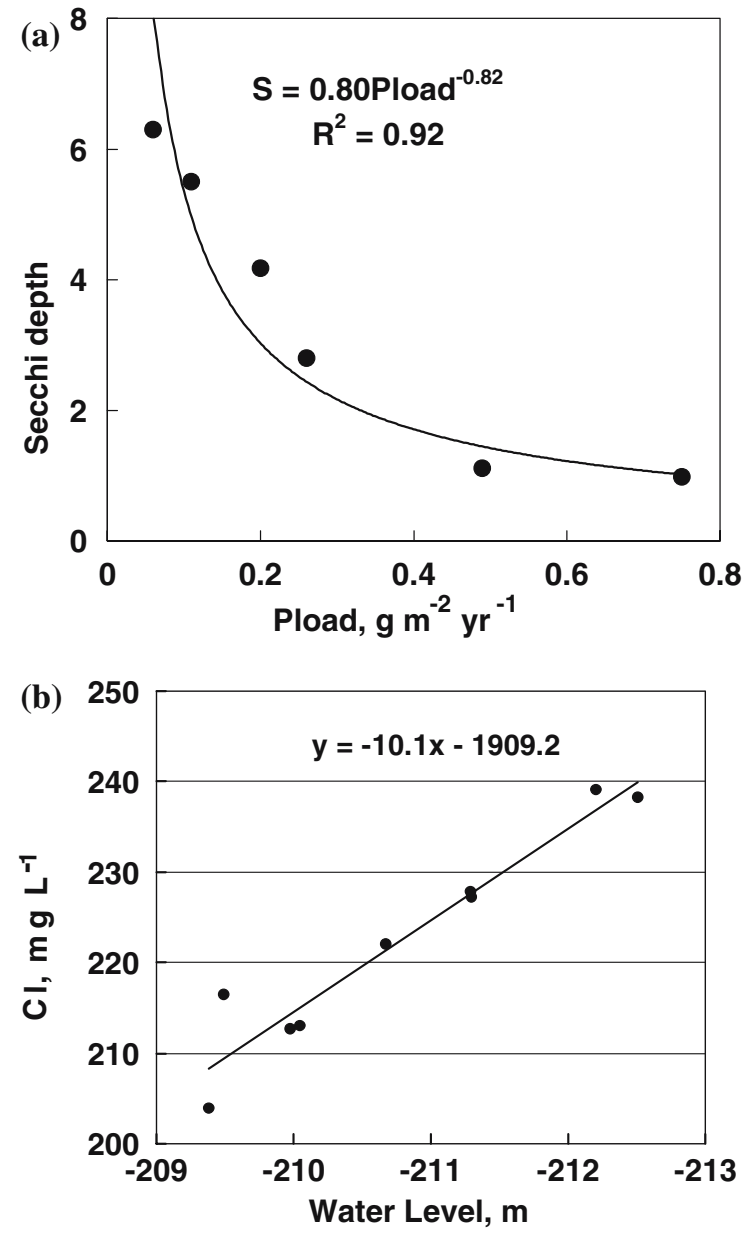

Figure 4. (a) Scattering plot and approximating regressional equation of the relationship between phosphorus load (Pload) and Secchi depth (S) in the Naroch Lakes. (b) Scattering plot and approximating regressional equation of the relationship between water level (as a proxy of the intensity of water supply) and chloride concentration $(\mathrm{Cl})$ in Lake Kinneret.

Nagels et al. (2001). For the Naroch lakes, the relative weights of the separate water quality indices were proportional to the square correlation coefficients of the respective temporal trends; for Lake Kinneret the relative weights were inversely proportional to the rating values of the water quality indices (Parparov \& Hambright, in preparation.).

Of course, the long-term dynamics of CWQI (Fig. 5) are different depending on the integration method used. The "average" CWQI varied within acceptable rating values: between 60 and 100, indicating no drastic deterioration of water quality in the both lakes. By contrast, the "minimum operator" method clearly indicated a significant
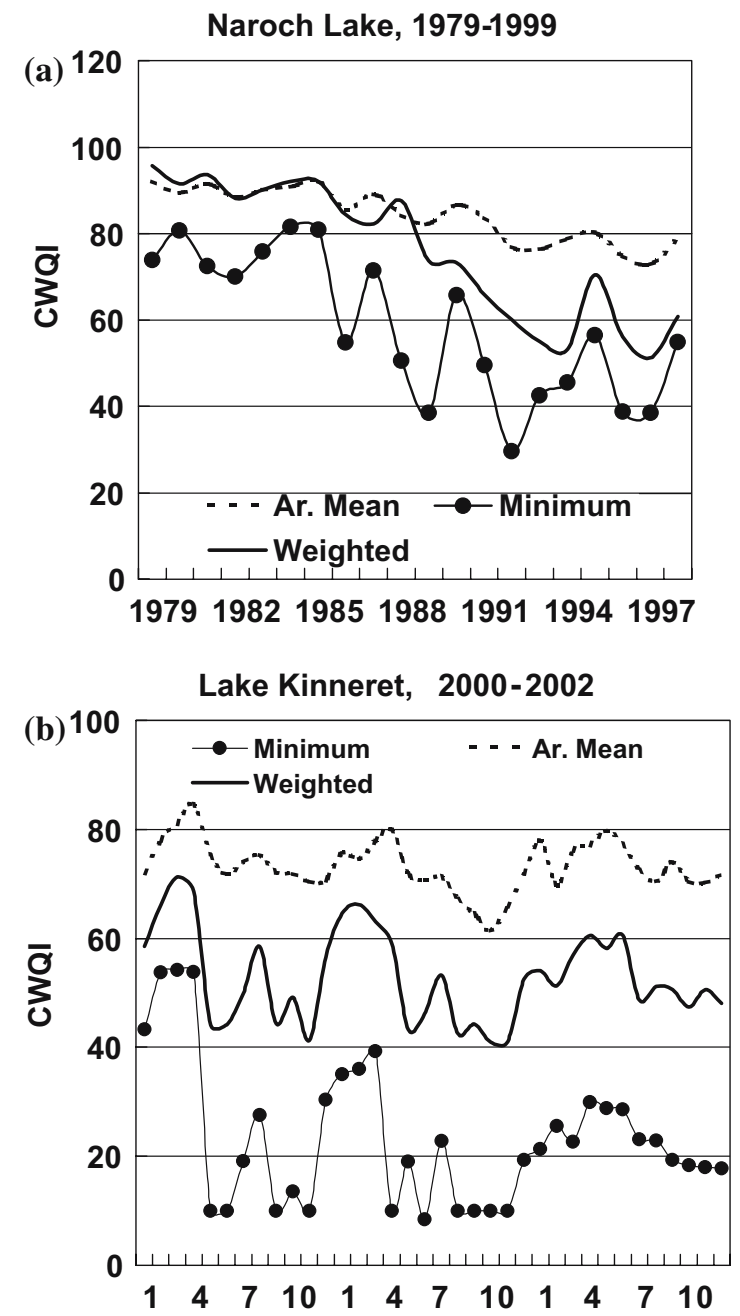

Figure 5. (a) Dynamics of the composite water quality index (CWQI) in Lake Naroch in 1979-1999. The CWQI was calculated as arithmetic mean (Ar. Mean), weighted average (Weighted), and using "minimum operator" of Smith (1987; 1990) ("Minimum"); (b) Dynamics of the composite water quality index (CWQI) in Lake Kinneret in 2000-2002. See Figure 5(a) for designations.

tendency toward deterioration of water quality. The "weighted average" method produced an intermediate value. Note that the different estimates of water quality dynamics for Lake Naroch indicated that oligotrophication yielded non-trivial WQ deterioration for all uses: conservation, recreation and fisheries.

Perhaps the most difficult aspect of WQI integration to resolve is that related to the choice of integration. The approaches suggested above, whether 'mean' and 'weighted' averages are not 


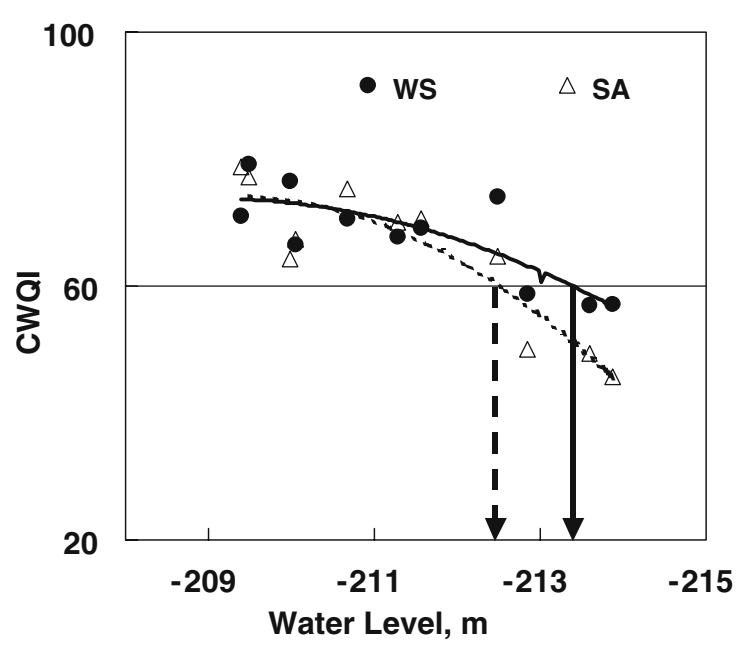

Figure 6. Scattering plot of the composite water quality index (CWQI, calculated as weighted average) versus water level in Lake Kinneret (as a proxy of the intensity of water supply). The calculations were done separately for the Winter-Spring and Summer-Autumn periods (WS and SA, respectively). The arrows indicate lower permissible ranges of the lake water level. The lowering of the lake water level below this value can lead to undesirable deterioration of the overall water quality.

objective and therefore reflect different interests of the different partners in water resources management.

Three considered approaches to calculating the composite water quality can be chosen under the following management strategies:

- CWQI calculated as the arithmetic average corresponds to a management strategy for which general WQ deterioration would be indicated by substantial deterioration of more than half of the separate WQIs;

- CWQI estimated using the minimum operator corresponds to a management strategy for which general WQ deterioration would be indicated by deterioration of only a singleWQI;

- CWQI estimated as the weighted average corresponds to a management strategy for which general WQ deterioration would be indicated by a combination of individual WQIs and the severity their deterioration (e.g., the lower or "worse" the rating value the higher its relative weight (Parparov and Hambright, in preparation). This system provides intermediate estimates of the overall water quality relative the above-mentioned approaches and corresponds to a viewpoint of a "pragmatic limnologist":
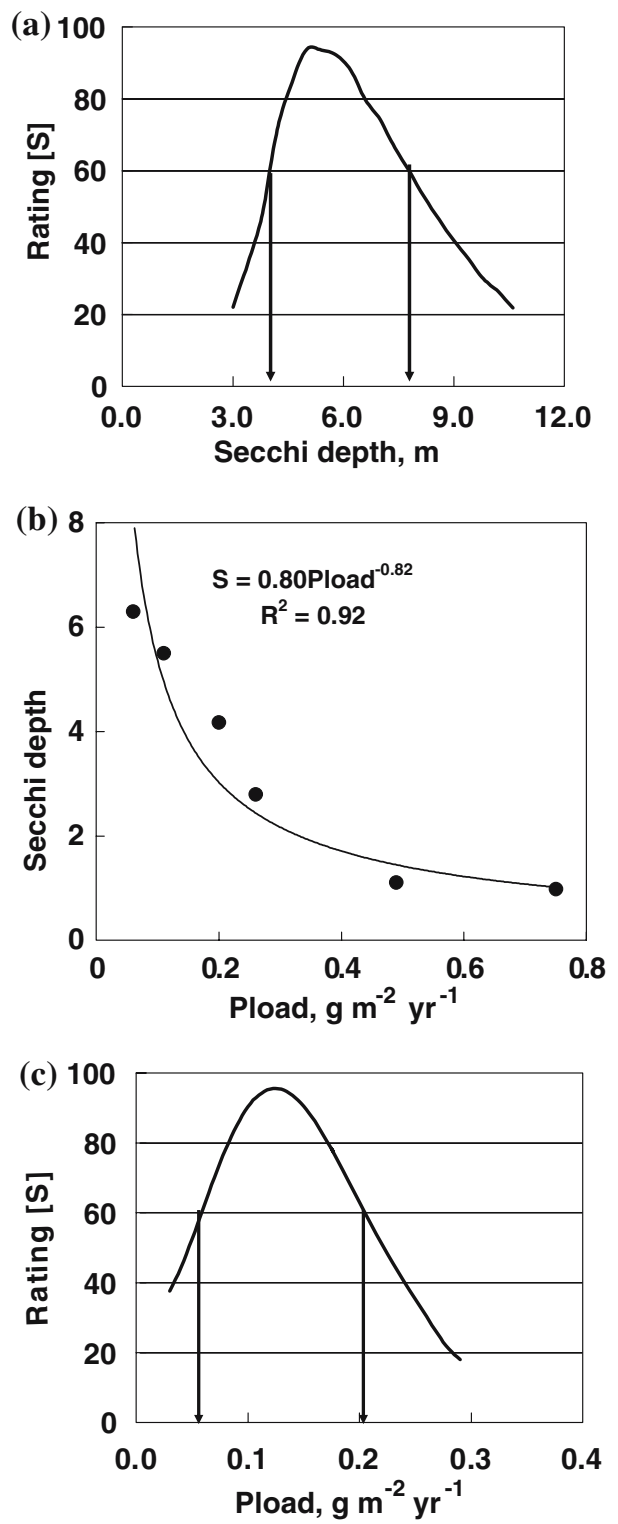

Figure 7. The steps of quantification of water quality (expressed as Secchi depth, S) in Lake Naroch. (a) The rating curve for $\mathrm{S}$. The arrows indicate permissible range of $\mathrm{S}(4.7<\mathrm{S}<7.9)$. Note, that both reduction and increase of transparency out of permissible range will be valuated as deterioration of water quality; (b) The interrelationship between phosphorus load (Pload, as a proxy of management measure) and S; (c) The direct interrelationship between water quality (as Rating of S) and the management measure (as Pload). The arrows indicate permissible range for Pload (the management measure): $0.07<$ Pload $<0.21$. It is important to note that the decrease of Pload below $0.07 \mathrm{~g} \mathrm{~m}^{-2} \mathrm{yr}^{-1}$ and the Pload increase above $0.21 \mathrm{~g} \mathrm{~m}^{-2} \mathrm{yr}^{-1}$ can stimulate water quality deterioration (due to oligotrophication or eutrophication, respectively). 
Assessment of potential ecological risk of management measures

A new step in the quantification of water resources management is to rank not only water quality but also to quantify actual management measures according to their potential ecological risk (Håkanson, 1999). The potential ecological risk (PER) of a management measure can be estimated (also by expert panel decision) as a product of the numerically expressed dimensionless values of the operational ecological effect variable (E) of a management measure, its areal distribution (A) (if applied to multiple lakes simultaneously) and time duration $(\mathrm{T})$ :

$$
\mathrm{PER}=\mathrm{E} \cdot \mathrm{A} \cdot \mathrm{T}
$$

If PER is calculated for a single entire lake, A will be a constant. Like the rating curves for various WQ parameters, E will be dependent on management strategy. For example, the disappearance of a particular species may be qualified by limnologists as an "ecological catastrophe" and therefore be assigned a very high value of E. However, drinking water suppliers may consider the extinction to be "insignificant" and therefore assign a the management strategy a relatively low value of $\mathrm{E}$.

\section{Quantification of the relationships between $W Q$ and management}

The most well-known and widely-used example of the relationship between WQ (expressed as chlorophyll concentration) and management measure (as phosphorus loading) is the Vollenweider-Dillon-Rigler concept relating phosphorus loading to the bioproductive parameters of a lake (Vollenweider, 1976; Dillon and Rigler, 1975). Such dependences are statistical and applicable to a given type of lakes, and therefore they have relatively high uncertainties for individual lakes.

Existing databases in many cases are not sufficient for establishing such relationships, particularly in cases of non-linear and non-monotonous relationships. A key direction in establishing the functional relationships between WQI and MM is the ecological modeling, interconnected by informational feedbacks with the management and limnological institutions, and therefore forming a self-organizing tool for water resources management (Parparov \&
Hambright, 1996). Search for the relationships $\mathrm{WQI}=\mathrm{Z}(\mathrm{MM})$ is one of the most exciting challenges for modern limnology: both theoretical and applied.

By combining equations (1) and (3) we establish a direct relationship between the quantitative estimates of water quality (as rating value, $\mathrm{R}$ ) with the intensity of the management measures (MM):

$$
\mathrm{R}=\mathrm{F}(\mathrm{MM})
$$

Such a relationship between management measure and the composite water quality (Fig. 6) should be especially important for communication with the water policy makers and specialists in environmental economy.

The above-described system (equations 1, 3 and 5) provides a direct correspondence between permissible ranges for water quality indices and permissible ranges for management measures:

$$
\left\{\mathrm{WQI}_{\text {LOW }} \text { WQI }<\mathrm{WQI}_{\mathrm{HIGH}}\right\} \Leftrightarrow\left\{\mathrm{MM}_{\text {LOW }} \mathrm{MM}<\mathrm{MM}_{\mathrm{HIGH}}\right\}
$$

The last expression provides the limits of management based on criteria of conservation of water quality. Being supplemented with the requirements of the socio-economical optimization, this expression could be considered as an operational definition of "sustainable management".

We illustrate the entire process of the WQ quantification with two examples for Lake Kinneret and Naroch Lake (Figs. 7 and 8). Note, that the obtained values of permissible ranges for the management measures are tentative because of absence of uncertainty analysis and/or possible hysteresis of the processes. Nevertheless, these examples illustrate the sequence of the steps necessary for the quantification of water quality.We emphasize again: the entire process of the water quality quantification, as a part of a management framework, must be strongly affected by the requirements of the management itself. Therefore, implementation of the expert panel method at each stage of the quantification process is unavoidable. Unfortunately, both water resources managers and limnologists often ignore this fact. The benefits from improvement of the interaction between the separate partners in the water resources management are obvious: establishment of a common language and quantifiable tools of management, transition from passive exploitation of water 

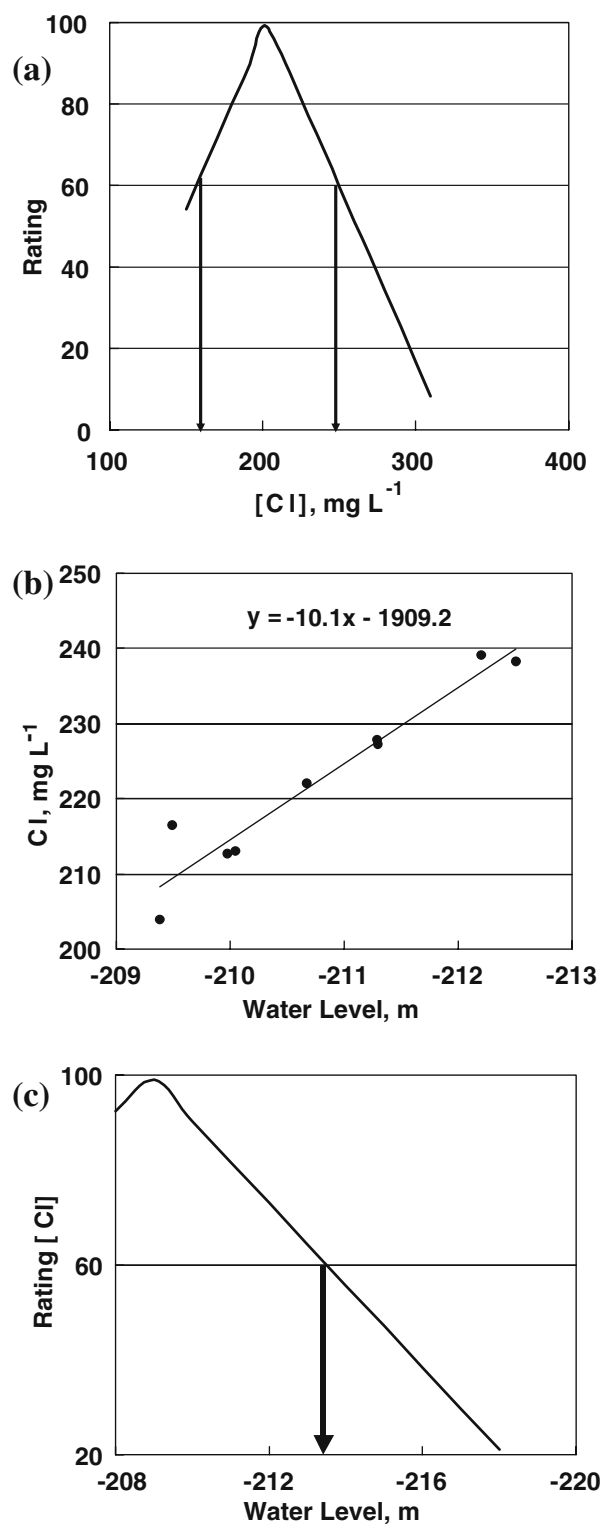

Figure 8. The steps of quantification of water quality in Lake Kinneret (expressed as chloride concentration, $\mathrm{Cl}$ ). (a) The rating curve for $\mathrm{Cl}$. The arrows indicate permissible range for $\mathrm{Cl}$ $(182<\mathrm{Cl}<244)$; (b) The interrelationship between water level (as a proxy of intensity of water supply), and $\mathrm{Cl}$; (c) The direct interrelationship between water quality (as $\mathrm{Cl}$ ) and the management measure (as water level). The arrow indicates the lower permissible range for water level (i.e., lowering of the lake water level below $-213.0 \mathrm{~m}$ will stimulate deterioration of water quality).

resources to quantitatively valuated management, and stimulation of new directions in theoretical limnology.

\section{Acknowledgements}

The authors are grateful to Prof. S. A. Ostroumov, Dr. J. K. Thompson, and Dr. R. Wotton for reviewing of the Manuscript.

\section{References}

Ben-Tuvia, A., E. B. Davidoff, J. Shapiro \& D. Shefler, 1992. Biology and management of Lake Kinneret Fisheries. The Israeli Journal of Aquaculture - Bamidgeh 44: 48-65.

Berman, T., L. Stone, Y. Z. Yacobi, B. Kaplan, M. Schlichter, A. Nishri \& U. Pollingher, 1995. Primary production and phytoplankton in Lake Kinneret: a long-term record (19721993). Limnology and Oceanography 40: 1064-1076.

Berman, T., Y. Z. Yacobi \& U. Pollingher, 1992. Lake Kinneret phytoplankton: stability and variability during twenty years (1970-1989). Aquatic Sciences 54: 104-127.

Boon, P. J., D. L. Howell, (eds), 1997. Freshwater quality: defining the indefinable? Scottish Natural Heritage, Edinburgh.

Brown, P. M., N. I. McClelland, R. A. Deninger \& R. G. Tozer, 1970. A water quality index - do we dare? Water \& Sewage Word, October 1970: 339-343.

Carlson, R. E., 1977. A trophic state index for lakes. Limnol. Oceanogr 22: 361-369.

Chapman, D., 1992. Water quality assessments . Chapman \& Hall, London.

Dillon, P. J. \& F. H. Rigler, 1975. A simple method for predicting the capacity of a lake for development based on lake trophic status. Journal of Fisheries Research Board Canada 32: $1511-1531$

Fozzard, I., R. Doughty, R. C. Ferrier, T. Leatherland \& R. Owen, 1999. A quality classification for management of Scottish standing waters. Hydrobilogia 395/396: 443-453.

Hakanson, L., 1999. Water pollution - methods and criteria to rank, model and remediate chemical threats to aquatic ecosystems. Backhuys Publishers, Leiden 299 pp.

Hakanson, L. \& R. H. Peters, 1995. Predictive limnology: methods for predictive modeling . SPB Academic Publishing, Amsterdam.

Hakanson, L., A. Parparov, A. Ostapenia, V. V. Boulion \& K. D. Hambright, 2000. Development of a system of water quality as a tool for management. Final report to INTAS, Uppsala university, Department of Earth Sciences 2000-11-07, $19 \mathrm{pp}$.

Hambright, K. D., M. Gophen \& S. Serruya, 1994. Influence of long-term climatic changes on the stratification of a subtropical, warm monomictic lake. Limnology and Oceanography 39: $1233-1242$.

Hambright, K. D. H., A. Parparov \& T. Berman, 2000. Indices of water quality for sustainable management and conservation of an arid region lake, Lake Kinneret (Sea of Galilee), Kinneret. Aquatic Conservation: Marine and Freshwater Ecosystems 10: 393-406. 
Horton, R. K., 1965. An index-number system for rating water quality. Journal of the water Pollution Control Federation. 37(3): 300-306.

Kalceva, R., J. V. Outrata, Z. Schindler \& M. Straskraba, 1982. An optimization model for the economic control of reservoir eutrophication. Ecological Modelling 17: 121-128.

Nagels, J. W., R. J. Davies-Colley \& D. G. Smith, 2001. A water quality index for contact recreation in New Zealand. Water Science and Technology 43(5): 285-292.

Ostapenya, A., 1999. Naroch Lakes: problems and forecasts. Lake ecosystems: biological processes, anthropogenic transformation, water quality. Proceedings of International Conference, 25 - 26 September, Minsk - Naroch: 282-292.

Ott, W., 1978. Water quality indices: a survey of indices used in the United States. Environmental Monitoring Series. EPA600/4-78-005, $128 \mathrm{pp}$.

Parparov, A. \& K. D. Hambright, 1996. A proposed framework for the management of water quality in arid-region lakes. Internationale Revue der Gesamten Hydrobiologie 81: 435-454.

Pollingher, U., 1978. The phytoplankton of Lake Kinneret. In Serruya, C. (ed.), Lake Kinneret, Dr Junk Publishers, The Hague: 229-242.

Pollingher, U., O. Hadas, Y. Z. Yacobi, T. Zohary \& T. Berman, 1998. Aphanizomenon ovalisporum (Forti) in Lake Kinneret. Israel, Journal of Plankton Research 20: 13211339.

Ryding, S.-O. \& W. Rast, 1989. The control of eutrophication of lakes and reservoirs. UNESCO, $314 \mathrm{p}$.
Serruya, C., (ed.), 1978. Lake Kinneret. Dr. Junk Publishers, The Hague, p. 502.

Shamir,U., J. Bear, N. Arad, Y. Gal-Noor, N. Selbst \& Y. Vardi, 1985. National water policy: a methodology and its application to Israel, IAHS Publ. No. 153: 369-379.

Smith, D. G., 1987. Water quality indexes for use in New Zealand's rivers and streams, Department of Scientific and Industrial Research, Water Quality Centre.

Smith, D. G., 1990. A better water quality indexing system for rivers and streams. Water Research 24: 1237-1244.

Straskraba, M. \& A. H. Gnauck, 1985. Freshwater Ecosystems. Modelling and Simulation. Development in Environmental Modelling, 8. Elsevier, 373 pp.

U. S. Environmental Protection Agency, 1974. An approach to a realative trophic index system for classifying lakes and reservoirs. National Eutrophication Survey. Working Paper No. 24.

Vollenweider, R. A., 1976. Advances in defining critical loading levels for phosphorus in lake eutrophication. Memorie dell' Istituto Italiano di Idrobiologia 33: 53-83.

WFD, 2000. Official text of the EU Water Framework Directive Published on 22 December 2000 in the Official Journal of the European Communities.

Winberg, G. G. (ed.), 1985. The Ecological System of the Naroch Lakes. Minsk (in rus.), 289 pp. 